\title{
Hafty w sztambuchach Biblioteki Uniwersyteckiej w Poznaniu
}

\begin{abstract}
Streszczenie. W artykule przedstawiono hafty znajdujące się $\mathrm{w}$ sztambuchach z XVIII i XIX wieku pochodzących ze zbiorów Biblioteki Uniwersyteckiej w Poznaniu. Omówione zostały zarówno technika wykonania haftów, jak i ich wartość artystyczna, a także znaczenie wskazanych przykładów dla historii hafciarstwa amatorskiego na ziemiach polskich. Artykuł jest jednocześnie próbą zwrócenia uwagi na istniejącą w tamtym okresie sztukę hafciarską o wyłącznie amatorskim charakterze oraz na kopiowanie i powtarzalność wzorów, co pozwala na określenie ich jako typowych dla danej epoki.
\end{abstract}

SŁowA KLUCzowe: sztambuchy, hafty, sztuka zdobnicza.

W XIX wieku popularne były drukowane poradniki - almanachy, noworoczniki i kalendarze zawierające teksty różnej natury, od użytecznych po rozrywkowe, dotyczące zarówno gospodarstwa, jak i życia rodzinnego czy towarzyskiego. Wśród tych licznych form modnej w XIX wieku "rozrywki literackiej"1 istniały również rękopiśmienne silva rerum, będące kroniką życia rodzin, a także sztambuchy.

Sztambuchy wywodzą się „,z dawnego uniwersyteckiego album amicorum i z dworskiej księgi pamiątkowej, w której zapisywano wiadomości o uroczystościach zaślubin, elekcji, koronacji, upamiętniano herby i godła obecnych na ceremoniach"2 ${ }^{2}$ Zwane również imionnikami lub albumami (ang. book of friend, łac. album amicorum), będące zbiorem autografów oraz wpisów „ku pamięci”, stały się ważnym elementem życia towarzyskiego arystokracji w XVIII i XIX wieku.

1 J. Kamionkowa, Almanachy literackie jako przejaw dziewiętnastowiecznej kultury popularnej, w: Formy literatury popularnej, red. A. Okopień-Sławińska, Wrocław 1973, s. 150.

2 Ibidem. 
Sztambuch - prowadzony przeważnie przez panny i panie (chociaż nie brak również sztambuchów należących do mężczyzn), do którego wpisywali się zarówno przyjaciele, jak i sławni bywalcy salonów - rozpowszechnił się z czasem także wśród klas średnich i „szybko przestał być czymś elitarnym"3 ${ }^{\prime 2}$ Przybrał formę bardziej popularna, głównie dzięki zastosowaniu ujednoliconych, sztampowych wpisów i formy pamiętnika, oraz formę Pêle-Mêle: rozmaitości, złotych myśli.

Jako „osobisty zbiór pamiątek ich właścicieli”4 wpisy sztambuchowe stały się szczególną formą okazywania przyjaźni i miłości, a w epoce romantyzmu wyrażały ducha epoki, pełniąc niejako funkcję cmentarzyska pamięci. Słowo pisane - niczym słowo wyryte na płycie nagrobnej miało zatrzymać przemijający czas i przyjaźń. Motyw cmentarza łączył się $\mathrm{w}$ romantyzmie $\mathrm{z}$ motywem ogrodu jako jedynego miejsca, w którym człowiek mógł zaznać szczęścia. Ogrody pełne były modnych wówczas ruin, a cmentarze obsadzano drzewami. Przenikanie się tych dwóch motywów - życia i śmierci - wpłynęło również na stylistyczny rozwój sztambucha, to jest ogrodu pamięci: od towarzyskich wpisów w swobodnej formie w kierunku wyrażania kultu przyjaźni i pamięci narodowej będących cmentarzyskiem pamięci. Sztambuch zyskał formę metaforyczną: „wpisy - kwiaty przyjaźni, sztambuch - ogród"5. Sztambuchowy zapis zawierał często, oprócz wpisu lub wiersza autora, elementy zdobnicze w postaci grafik, rysunków, akwarel, a nawet haftów. Jak wspomina Artur Jazdon: „Poprzez badanie formy zewnętrznej, porównanie charakteru dokonywanych wpisów i stylu, w jakim to czyniono, możemy dokładnie prześledzić zmiany zachodzące w obowiązującej modzie, np. na panujący styl estetyczny"6.

Sztambuchy znajdujące się w zbiorach Biblioteki Uniwersyteckiej w Poznaniu zawierają ciekawe przykłady haftów, które sygnalizują różne koncepcje estetyczne: od stylu Ludwika XVI, poprzez biedermeier, po styl z motywami romantycznymi.

Pierwszy z prezentowanych $\mathrm{w}$ artykule sztambuchów należał do M.Ch. Augusta Fiedlera. Zawiera wpisy z lat 1789-1813 (rkp. 3126).

${ }^{3}$ A. Jazdon, Sztambuchy, Poznań 2003, s. 2.

${ }^{4}$ J. Litwinek, Sztambuchy literackie XIX wieku w zbiorach rękopiśmiennych Biblioteki Ossolineum, "Ze skarbca kultury” 1979, z. 32, s. 49.

${ }^{5}$ J. Jania, O sztambuchu romantycznym, w: Acta Universitatis Wratislaviensis, Prace Literackie XIX, Wrocław 1977, s. 61.

${ }^{6}$ A. Jazdon, Sztambuchy w zbiorach poznańskich, "Studia i Materiały do Dziejów Wielkopolski i Pomorza" 1982, t. XIV, z. 2, s. 129. 


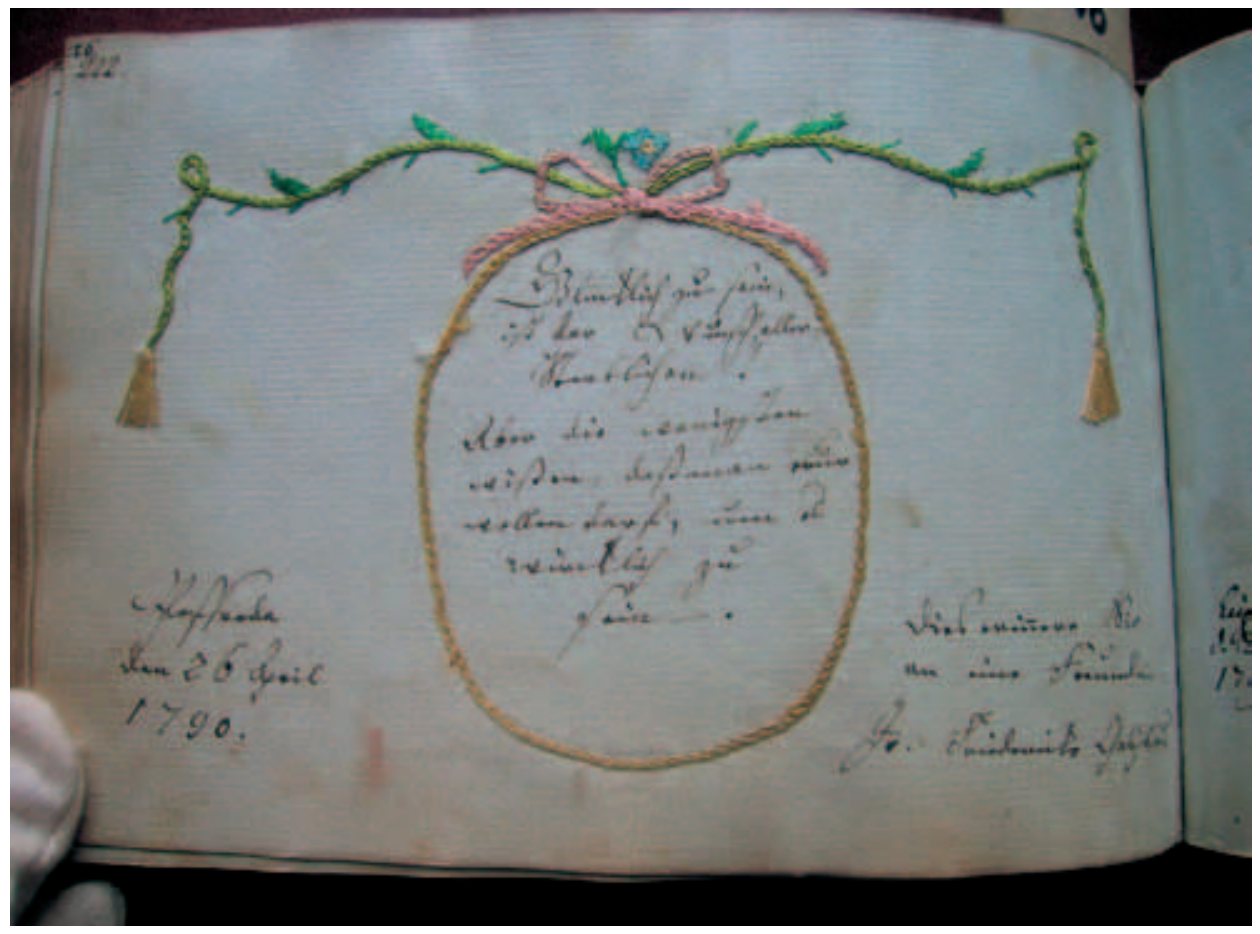

Fot. 1. Haft ze sztambucha Augusta Fiedlera

Widoczny na zdjęciu haft (fot. 1$)^{7}$ jest haftem dekoracyjnym, okalającym sztambuchowy wpis z roku 1790. Delikatne elementy kwiatowe i sznur, zakończony chwostami, wskazują wyraźnie na haft XVIII-wieczny w stylu Ludwika XVI ${ }^{8}$."Silny naturalizm i rytmiczność coraz wyraźniej tu występuja linia falista wydłużona zaznacza swą przewagę" ${ }^{\prime \prime}$. Zastosowane kolory są typowe dla haftów tej epoki: dominują zimne odcienie, takie jak bladoniebieski i bladoróżowy. Ze znajdujących się na karcie niewyraźnych wpisów łatwo rozszyfrować datę „den 26 April 1790” (26 kwietnia 1790) $)^{10}$.

${ }^{7}$ Fotografie haftów z kolekcji sztambuchów Biblioteki Uniwersyteckiej w Poznaniu wykonała Alicja Szulc.

${ }^{8}$ Zob. T. Mańkowski, Polskie tkaniny i hafty XVI-XVIII wieku, Wrocław 1954, s. 133.

${ }^{9}$ E. Świeykowski, Zarys artystycznego rozwoju tkactwa $i$ hafciarstwa objaśniony zabytkami Muzeum Narodowego w Krakowie: z XXV tablicami, s. 178, Kraków, Małopolska Biblioteka Cyfrowa, 2009 [online], [dostęp: 19.04.2011], dostępny w internecie: http:// mbc.malopolska.pl/dlibra/docmetadata?id=16158\&from=publication\&.

${ }^{10}$ Odczytanie i tłumaczenie tekstów niemieckich - Renata Piejko. 


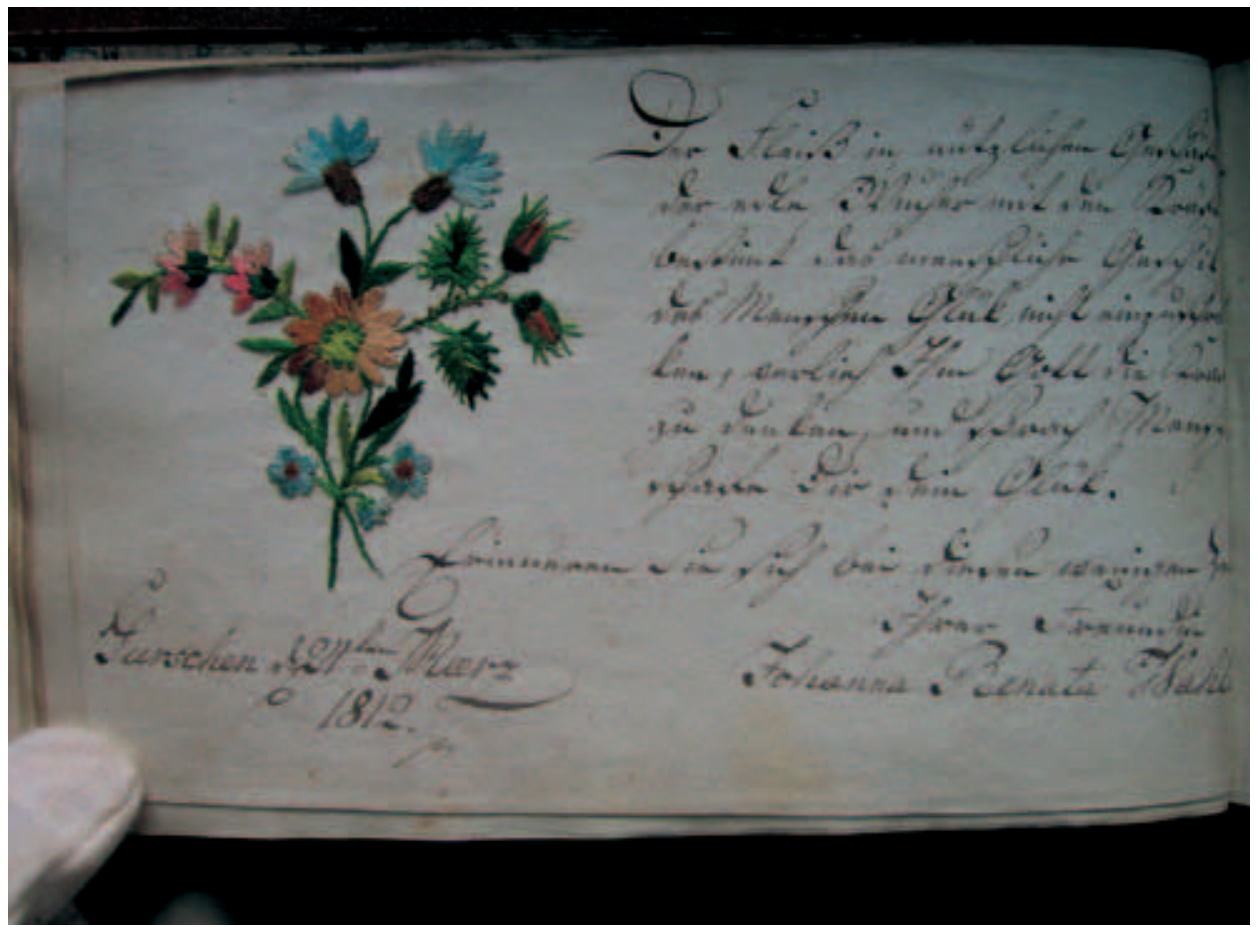

Fot. 2. Haft ze sztambucha Augusta Klemba

Kolejny haft zasługujący na szczególną uwagę (fot. 2 i 3) znajduje się w sztambuchu Augusta Klemba z Rawicza (rkp. 378 I).

Jest to haft w stylu biedermeier, zawierający motyw roślinny, konkretnie motyw naturalnie zebranych $\mathrm{w}$ bukiet kwiatów, których symbolika miała duże znaczenie w tej epoce. Mimo iż pochodzi z 1812 roku, a więc powstał na trzy lata przed oficjalną data, która zapoczątkowała biedermeier, wyraźnie wskazuje już na ten styl zdobniczy.

$\mathrm{Na}$ taką interpretację pozwalają dwa elementy. Przede wszystkim motyw bukietu składającego się z różnych kwiatów, bez stylizacji widocznej w poprzednim hafcie, a także region, z którego haft pochodzi. Wykonany został w Wielkopolsce, w zaborze pruskim, na ziemiach będących pod wpływem kultury niemieckiej, w której ten styl dominował. Haft charakteryzują: bogata kolorystyka bukietu, precyzja wykonania i (co najciekawsze) dwustronność - lustrzane odbicie: po jednej i po drugiej stronie sztambuchowej karty widnieje ten sam wzór, wykonany z wielką precyzją. Bukiet kwiatów składa się z pięciu gatunków roślin. Łatwe do rozpoznania są modrak i róża, trzy niezapominajki i dwie inne, nieznane mi rośliny. Wszystkie elementy tych roślin - łodygi, pąki, liście - wykonano z dbałością o najdrobniejszy szczegół, co przy tak 


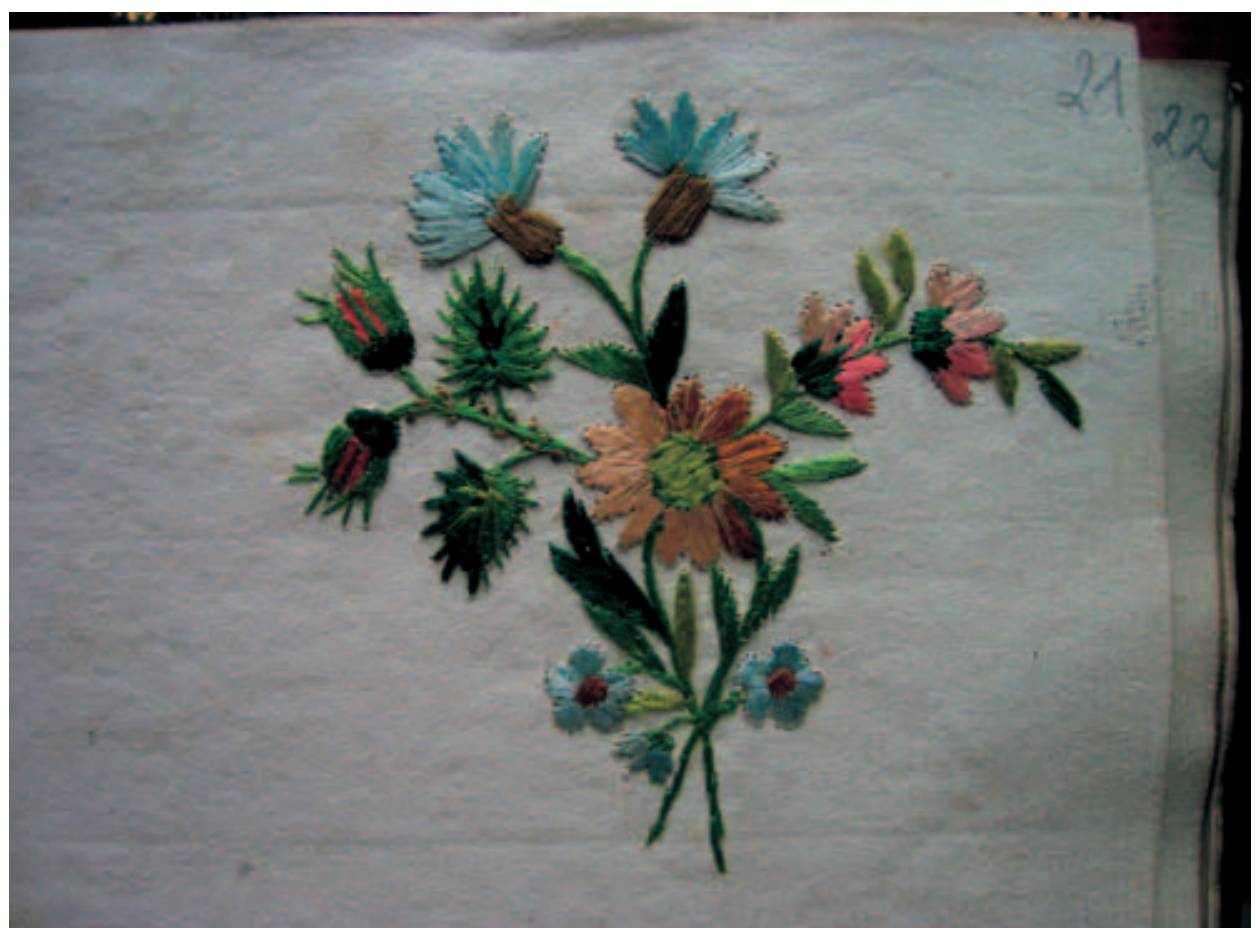

Fot. 3. Haft ze sztambucha Augusta Klemba

małym hafcie, w dodatku wykonanym na papierze, pozwala docenić kunszt autora.

Haft znajduje się po lewej stronie karty i stanowi element wpisu, którego treść brzmi: „Der Fleiss in nützlichen Geschäften/ Der Wucher mit den Edlen kräften/ Bestimmt das menschliche Geschick/ Der Menschen Glück nicht einzuschränken/ Verlieh ihm Gott die Kraft zu denken/ Und sprach Mensch schaff dein und deiner Brüder Glück/ Erinnern Sie sich bei diesen [...]/ Ihrer Freundin/ Johanna Renata [...]" (Pilność w użytecznych sprawach/ korzystanie z cennych (szlachetnych) sił/ wyznaczają ludzkie losy (decydują o ludzkich losach)/ By nie ograniczać szczęścia ludzi/ Bóg dał im zdolność myślenia i powiedział/ Człowiecze, dawaj szczęście sobie i swoim braciom/ Przy tych słowach proszę wspomnieć swoją przyjaciółkę/ Johannę Renatę [...]). Pod haftowanym bukietem znajduje się data i miejsce wpisu: „Gurschen, den 24 März 1812” (Gurschen = Górczyna, 24 marca 1812).

Ostatni ze sztambuchów zawiera największą liczbę haftów, zarówno tych w stylu biedermeier, jak i tych w stylu romantycznym. Właścicielem tego sztambucha był G. Fliege (rkp. 380) z Poznania. „Sztambuch należący do G. Fliegego z Poznania i zapisany w latach 1823-1845 jest 


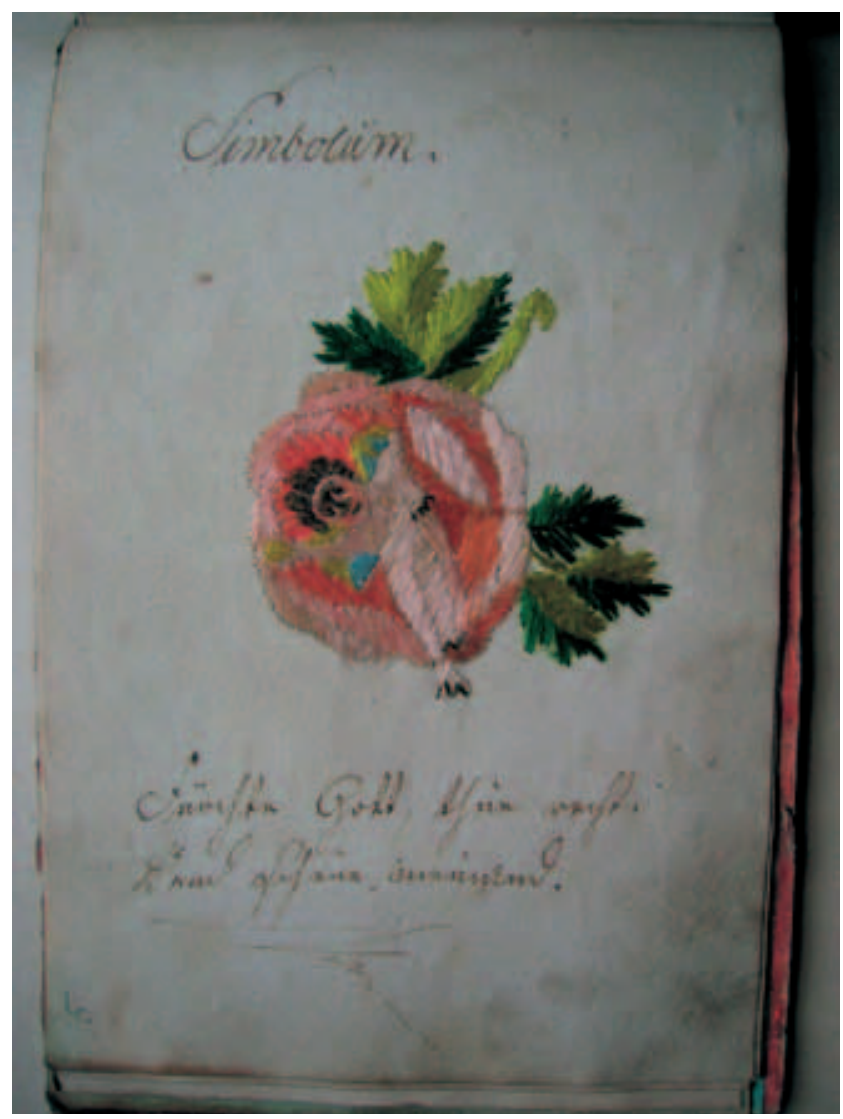

Fot. 4. Haft ze sztambucha G. Fliegego

ciekawy z uwagi na ilustracje wykonane farbą, a także kilka haftów"11. Widoczne są tam cztery hafty. Trzy pierwsze to kwiaty wkomponowane w tekst, dwie róże i niebieski kwiat, być może niezapominajka. Kwiaty te nawiązują do tematyki roślinnej, popularnej w obu wymienionych stylach. Czwarty haft przedstawia fragment ogrodu.

Pierwszy haft (fot. 4) przedstawia kwiat róży z kilkoma liśćmi. Mimo że jest wykonany techniką haftu płaskiego zwykłego, autor starał się nadać wielowymiarowość przedstawianej formie przez zróżnicowanie barw i zastosowanie odcieni. Na środku strony znajduje się róża. Nad nią widnieje napis: „Simbolum” (Kredo), a na dole wpis: „Fürchte Gott, Tue recht, Scheue niemanden" (Bój się Boga, czyń dobrze i nie obawiaj się nikogo).

Kolejny haft (fot. 5), przedstawiający również różę, jest bogatszy o inne elementy roślinne. $\mathrm{W}$ centrum znajdują się kwiat róży na łodydze i dwa

\footnotetext{
${ }^{11}$ A. Jazdon, Sztambuchy, s. 3.
} 


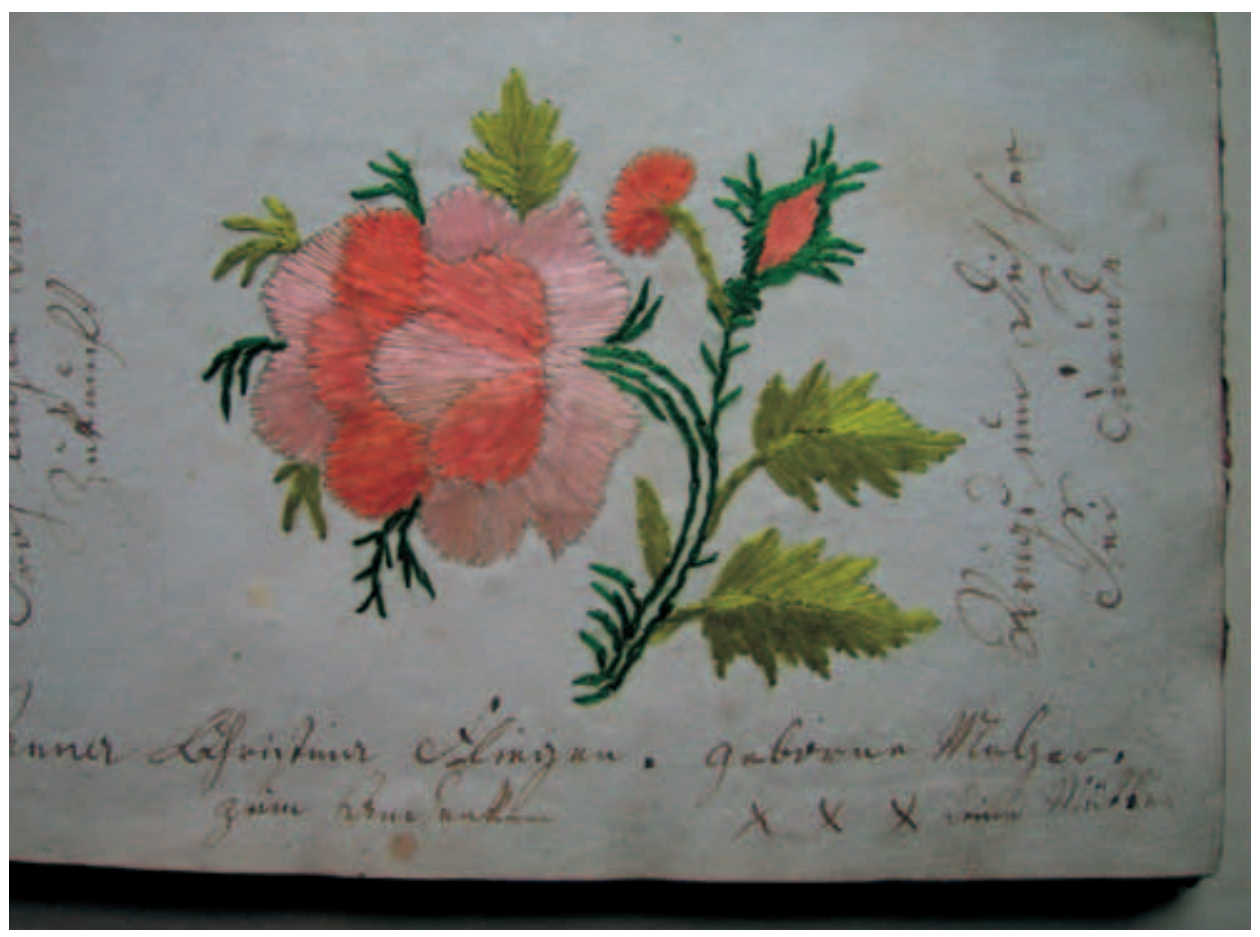

Fot. 5. Haft ze sztambucha G. Fliegego

pączki: rozwijający się oraz jeszcze zamknięty. Haft ten nie zachowuje proporcji rośliny, ale zawiera wiele drobnych elementów, które tworzą interesującą całość. Okalający wpis dał się odczytać jedynie fragmentarycznie: „Froh lächle Dir Zukunft” (Radośnie uśmiecha się do Ciebie przyszłość), a strofom wierszyka towarzyszy podpis: „Anna [...] zum Andenken" (Anna [...] na pamiątkę).

Trzeci haft (fot. 6) z omawianego sztambucha to niepozorna, kwitnąca na niebiesko roślina, która - jak sądzę - jest kompilacją wielu roślin kwiatowych. Niebieskie płatki to być może niezapominajka, białe - rumianek, a zamknięty pączek sugeruje różę. Haft ten umieszczono po lewej stronie sztambuchowej karty wraz z niewyraźnym wpisem. Pod haftem umieszczone zostały dwie krótkie noty, jedna z datą i miejscem wpisu: „Wollstein den 19 März 1826" (Wolsztyn, 19 marca 1826).

Bardzo interesujący wydaje się ostatni haft ze sztambucha Fliegego (fot. 7), najbliższy metaforze sztambucha jako ogrodu-cmentarzyska pamięci. Fragment ogrodu - zielonego trawnika z wyrastającymi ponad ziemię roślinami, pochylającym się drzewem i opartą o nie tablica, niczym płytą cmentarną - jest kolejnym, obok rycin zamieszczanych w sztambuchach, nawiązaniem do epoki romantyzmu. Haft ten rozmieszczono 


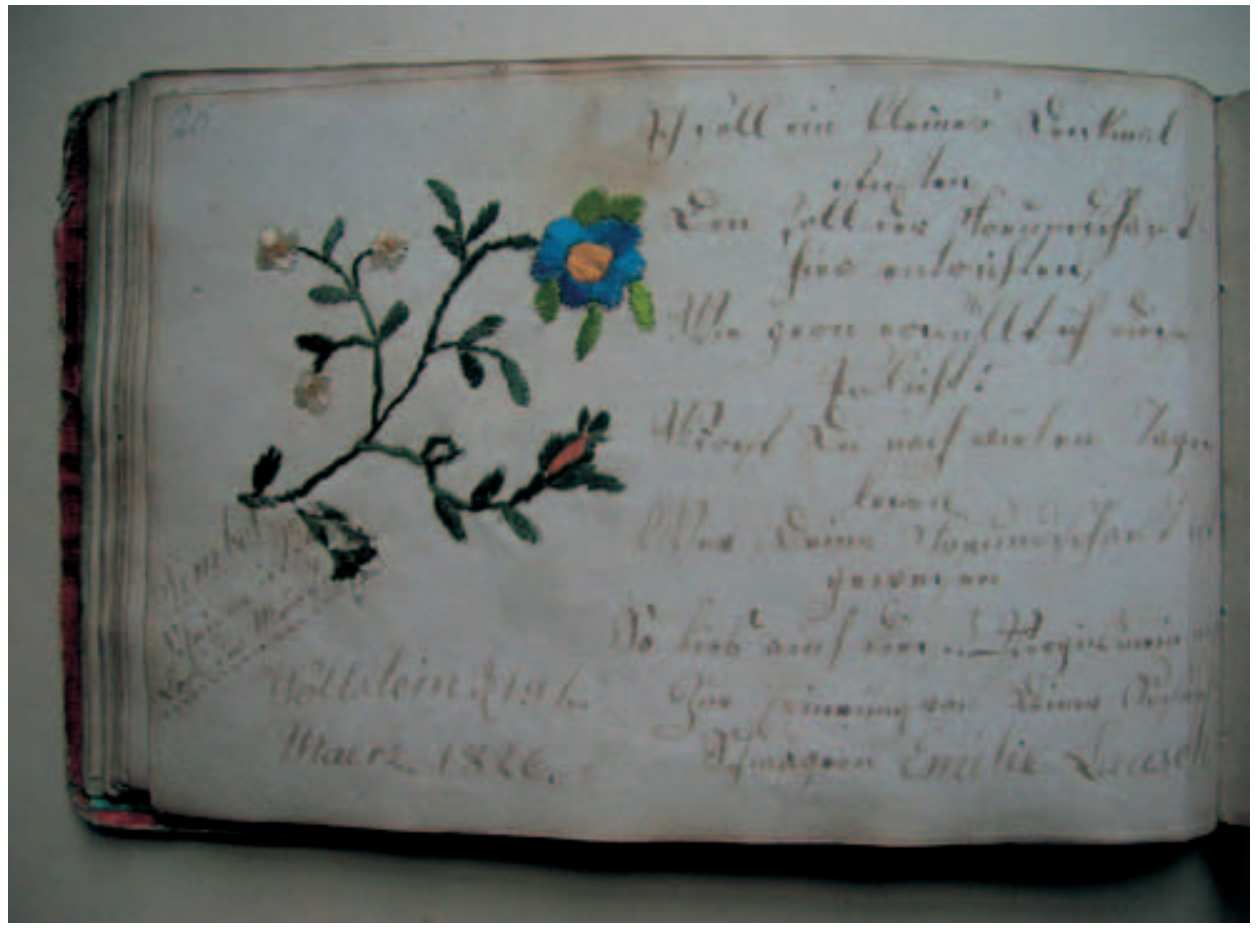

Fot. 6. Haft ze sztambucha G. Fliegego

na całej stronie, bez żadnych wpisów. Jedynie tablica oparta o drzewo zawiera notę: "Zur Erinnerung" (na pamiątkę) i datę „1827".

Wykonany techniką haftu płaskiego tworzy, moim zdaniem, nieładne, barwne plamy, które - w założeniu autora - miały zapewne przenikać się i tworzyć jednolity obraz trawnika. Gdyby autor zastosował technikę haftu płaskiego cieniowanego, uzyskałby pożądany efekt przenikających się odcieni. Nie wiadomo, kim jest autor tego haftu, najprawdopodobniej to osoba niezbyt jeszcze biegła w sztuce hafciarskiej, stąd pewne braki i widoczna nieudolność w wykonaniu trudniejszych elementów.

Pewnym utrudnieniem dla twórców przedstawionych powyżej haftów jest materiał, na którym zostały one wykonane, tj. papier, nietypowy dla tej sztuki. Materiał niełatwy, nie tylko ze względu na brak elastyczności (haftowano przecież na tamborkach, dzięki czemu napięta tkanina przypominała papier), ale przede wszystkim ze względu na możliwość łatwego uszkodzenia lub rozdarcia. Przyglądając się sztambuchowym haftom, wyraźnie widać nakłucia, przez które przeprowadzono nić. Można również dostrzec niewykorzystane nakłucia, szczególnie w hafcie ze sztambucha Fliegego (rkp. 380), przedstawiającym cmentarny ogród. Warto zadać pytanie, czy haft był poprawiany i stąd te zbędne nakłucia, 


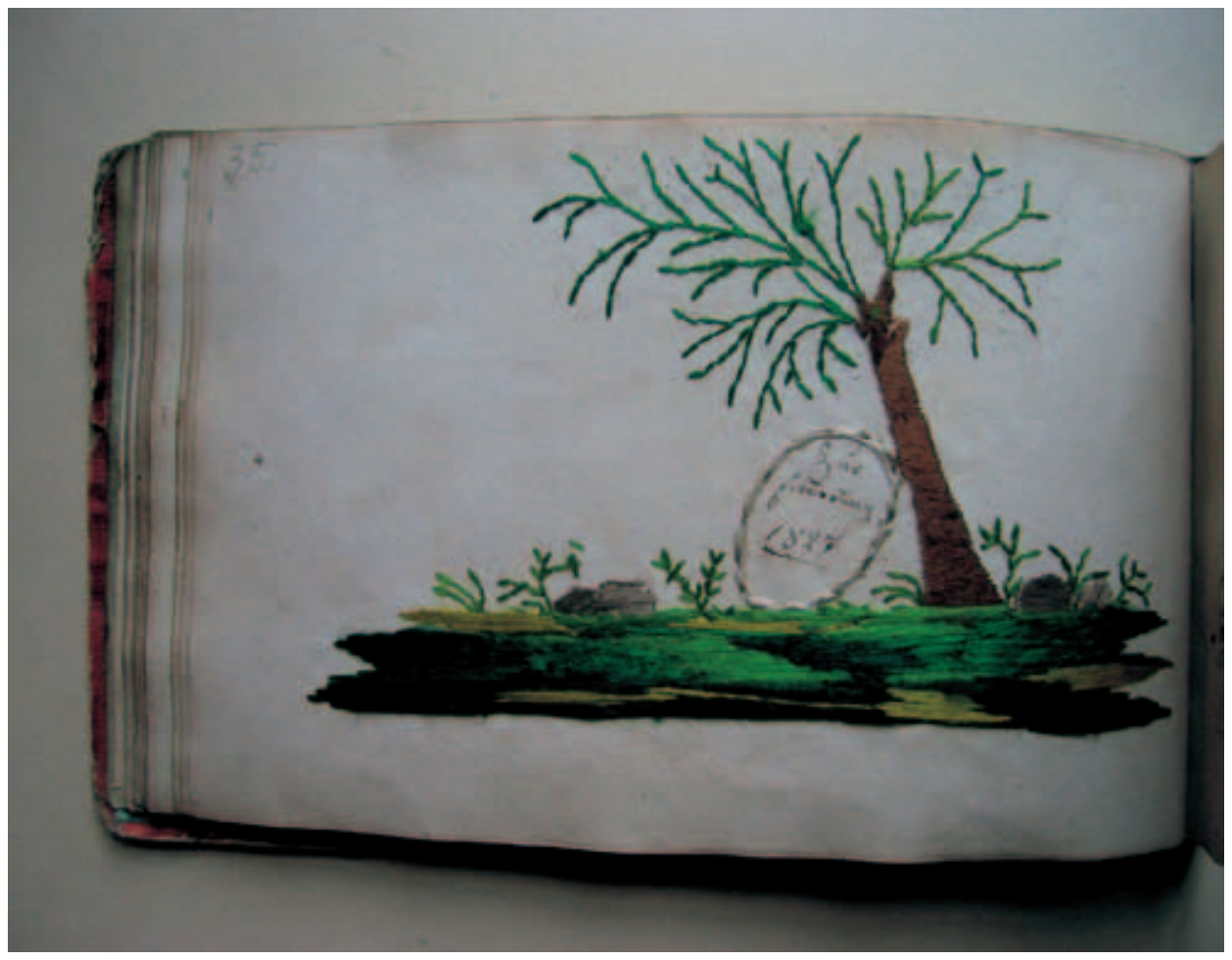

Fot. 7. Haft ze sztambucha G. Fliegego

czy też nakłuwano papier wcześniej, a w trakcie pracy koncepcja obrazu zmieniła się i pewne elementy pozostały niewykorzystane.

W piśmiennictwie rodzimym istnieje niewiele przykładów „polskich” świeckich haftów amatorskich, a przede wszystkim mało jest prac krytycznych na ten temat. Hafty zawarte w sztambuchach stanowią jednocześnie przykład i dowód na użycie tej formy sztuki zdobniczej nie tylko do ozdoby ubrań, bielizny stołowej i osobistej, lecz również do tworzenia pamiątek. Można zatem pozwolić sobie na stwierdzenie, że pojawienie się haftu na kartach XVIII-wiecznego i XIX-wiecznego sztambucha wskazuje na popularność tego rodzaju zdobnictwa.

Warto podkreślić w tym miejscu zwrot "świeckie hafty amatorskie” dla odróżnienia ich od innych rodzajów haftów. Do dziś zachowało się bowiem wiele haftów wykonywanych w klasztorach żeńskich oraz haftów związanych z obrządkiem liturgicznym, takich jak haftowane ornaty czy obrusy, jak również suknie, kamizelki, a także makaty powstałe w manufakturach lub cechach hafciarskich. Niewiele jest natomiast przykładów haftów wykonywanych przez kobiety lub mężczyzn w domach oraz wzmianek na ten temat. Julian Kołaczkowski w Wiadomościach tyczacych 
sie przemystu i sztuki w dawnej Polsce ${ }^{12}$ wspomina o haftach tworzonych przez królową Jadwigę, Annę Jagiellonkę oraz Marię Leszczyńską: znajdowały się one w skarbcach katedry krakowskiej i częstochowskiej. Nie ma jednak opracowań na ten temat i nie wiadomo, czy te hafty zachowały się do dziś.

Przymiotnika „polskie” użyłam w cudzysłowie ze względu na brak pełnych informacji o autorach haftowanych wpisów. Nazwy miejscowości wskazują na teren dawnej i dzisiejszej Polski, natomiast nazwiska pod wpisami są niemieckie, tak jak język samych wpisów. Historyczne powiązania tych terenów z kulturą zarówno polską jak i niemiecką pozwalają na stwierdzenie, że jeśli nawet hafty te nie są haftami absolutnie polskimi, to użyte motywy, barwy i sposób wykonania pozostają uniwersalne dla tego okresu.

Z nielicznych i ogólnych rozpraw na temat hafciarstwa wynika, że w XVIII wieku przestało ono być rzemiosłem, stając się wyłącznie zajęciem dla kobiet ${ }^{13}$. Swoją popularność odzyskało częściowo w drugiej połowie XIX wieku, choć znacznie obniżył się poziom artystyczny haftu, który był odtąd głównie ozdobą mieszczańskich domów ${ }^{14}$. Haft stał się zajęciem dla kobiet $\mathrm{i}$ - podobnie jak sztambuch - został sprowadzony do rangi elementu życia towarzysko-kulturalnego klasy mieszczańskiej. O ile w wiekach średnich powstawały na dworach szkółki hafciarskie ${ }^{15}$, o tyle w programach kształcenia XIX-wiecznych pensji żeńskich uwzględniano roboty ręczne ${ }^{16}$, a w czasopismach kobiecych pojawiały się ogłoszenia o kursach haftu, szycia i kroju ${ }^{17}$.

Warto zadać pytanie o pochodzenie wzorów, a więc o źródła, z których korzystały hafciarki. Być może same projektowały wykonywane hafty. Czy wzory były powtarzane, niemal banalne, czy autor haftu był jedynie odtwórcą gotowego wzoru, czy też sam projektował wykonany haft? Wiadomo, że wielką popularnością cieszyły się wzorniki robót kobiecych ${ }^{18}$, drukowane między innymi w prasie kobiecej, z której wzory powtarzano

${ }^{12}$ J. Kołaczkowski, Wiadomości tyczace się przemystu i sztuki w dawnej Polsce, Kraków 1888, s. 208.

13 Zob. T. Mańkowski, op.cit., s. 133.

${ }^{14}$ Zob. ibidem, s. 144.

${ }^{15}$ Zob. J. Kołaczkowski, op.cit., s. 204.

${ }^{16}$ Zob. M. Stawiak-Ososińska, Ponętna, uległa, akuratna...: ideał $i$ wizerunek kobiety polskiej pierwszej połowy XIX wieku (w świetle ówczesnych poradników), Kraków 2010, s. 59.

17 Zob. E. Kowecka, W salonie i w kuchni: opowiesść o kulturze materialnej pałaców i dworów polskich w XIX w., Poznań 2008, s. 235.

18 Torebki, sakiewki i portfele ze zbiorów Muzeum Narodowego w Krakowie, Kraków 2009, s. 41. 
w wielu pracach. We Francji, w Anglii, w Holandii czy w Stanach Zjednoczonych zachowało się wiele zabytków świeckiego hafciarstwa amatorskiego w postaci na przykład sammplerów, czyli wzorników ${ }^{19}$. Inaczej jest w Polsce: tu nie istnieją takie zabytki, które pozwoliłyby na porównanie użytych motywów i określenie jakiejś powtarzalności, czyli kopiowania raz użytych wzorów. Nie wiadomo też, czy wpłynęły na mniejszą lub większą popularność haftów. Postanowiłam więc porównać wykorzystane w sztambuchach wzory z innymi haftami polskimi z tego okresu.
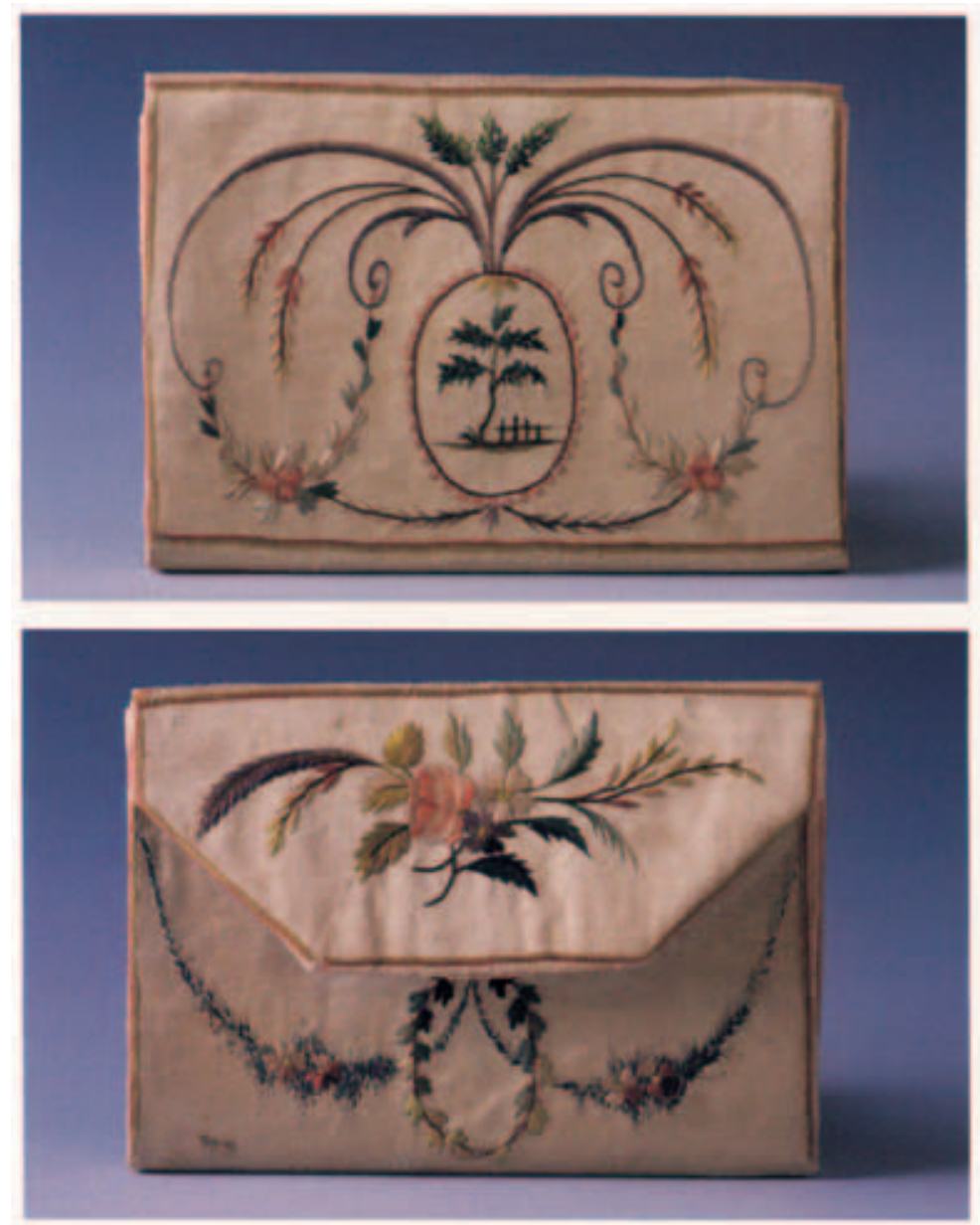

Il. 1. Portfel atłasowy z katalogu Torebki, sakiewki i portfele ze zbiorów Muzeum Narodowego w Krakowie (s. 276)

19 http://tennesseesamplers.blogspot.com [dostęp: 8.08.2011], http://needleprint. blogspot.com [dostęp: 8.08.2011], http://www.merklappen.nl/collectie.html [dostęp: 8.08.2011]. 
Dostępnym przykładem są torebki i portfele ze zbiorów Muzeum Narodowego w Krakowie. Katalog Torebki, sakiewki i portfele ze zbiorów Muzeum Narodowego w Krakowie zawiera wiele przykładów haftów o stylistyce zbliżonej do haftów sztambuchowych, pochodzących z kolekcji Biblioteki Uniwersyteckiej. Haft z 1790 roku ze sztambucha M. Ch. Augusta Fiedlera (rkp. 3126, fot. 1) nawiązuje do haftu zamieszczonego na portfelu z przełomu XVIII i XIX wieku (nr inw. MNK XIX-3519, il. 1). Pejzaż w owalnym medalionie zastąpiono sztambuchowym wpisem, a sznur z drobnymi roślinami okalający medalion jest podobny do - bogatego w kwiaty i trawy - zdobienia widocznego na rewersie atłasowego portfela.

Przykładem haftu kwiatowego - bardzo zbliżonego formą do haftu ze sztambucha Augusta Klemba z Rawicza (rkp. 378 I, fot. 2 i 3) - jest atłasowy portfel na listy z końca XVIII wieku (nr inw. MNK XIX-3525, il. 2), przedstawiający wiązankę kilku gatunków kwiatów.
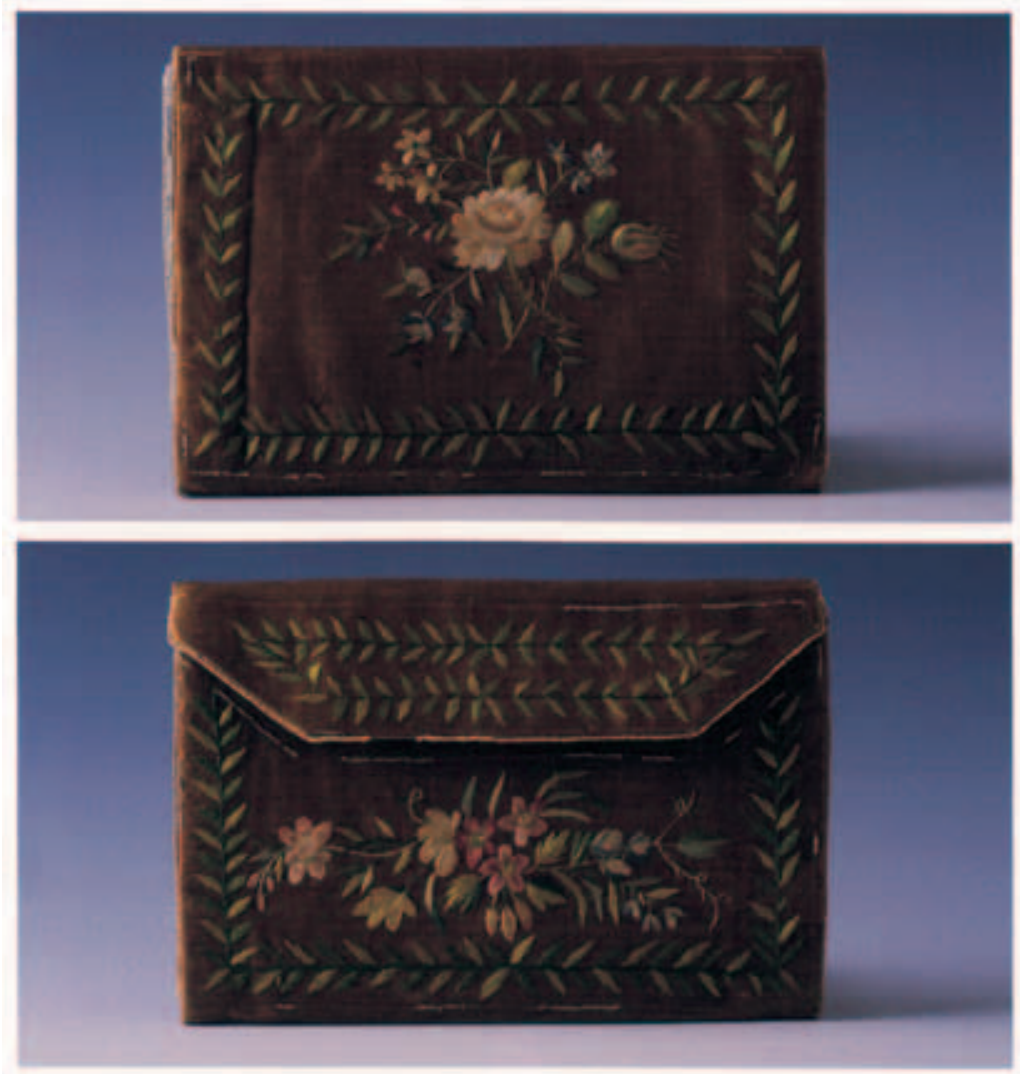

Il. 2. Portfel atłasowy na listy z katalogu Torebki, sakiewki i portfele ze zbiorów Muzeum Narodowego w Krakowie (s. 268) 

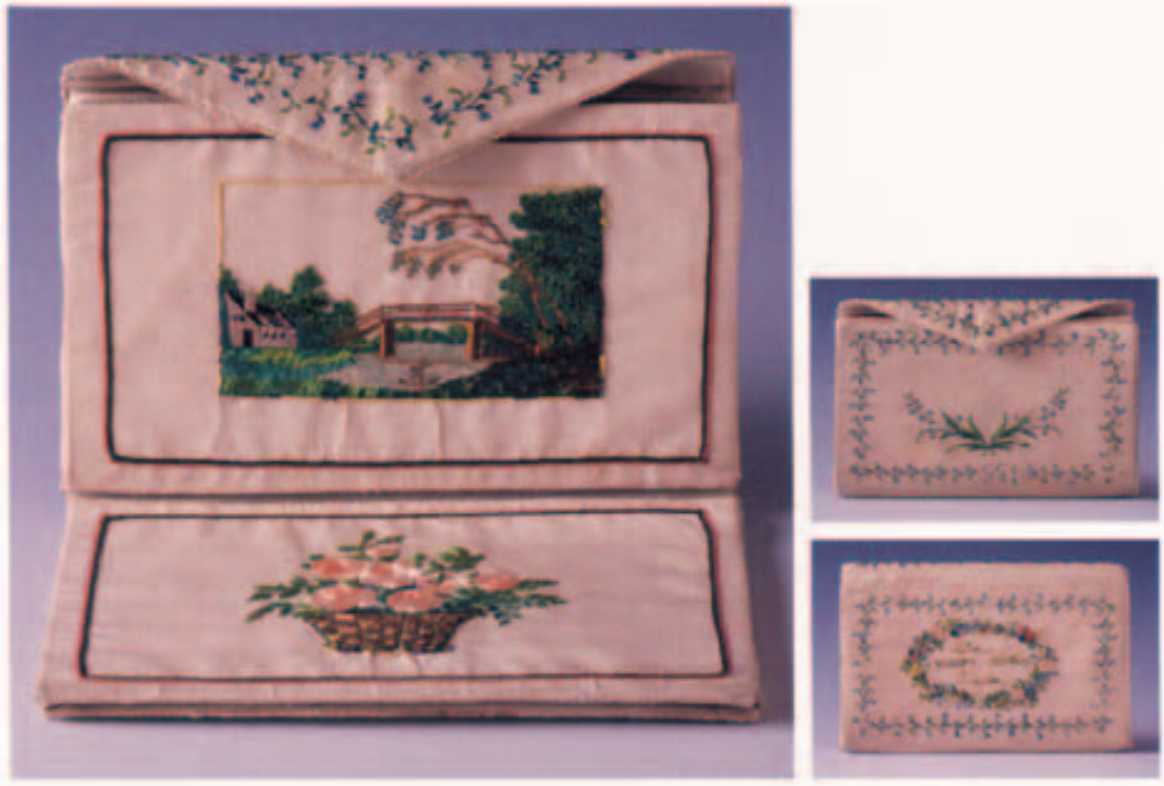

Il. 3. Portfel z białej tafty z katalogu Torebki, sakiewki i portfele ze zbiorów Muzeum Narodowego w Krakowie (s. 291)
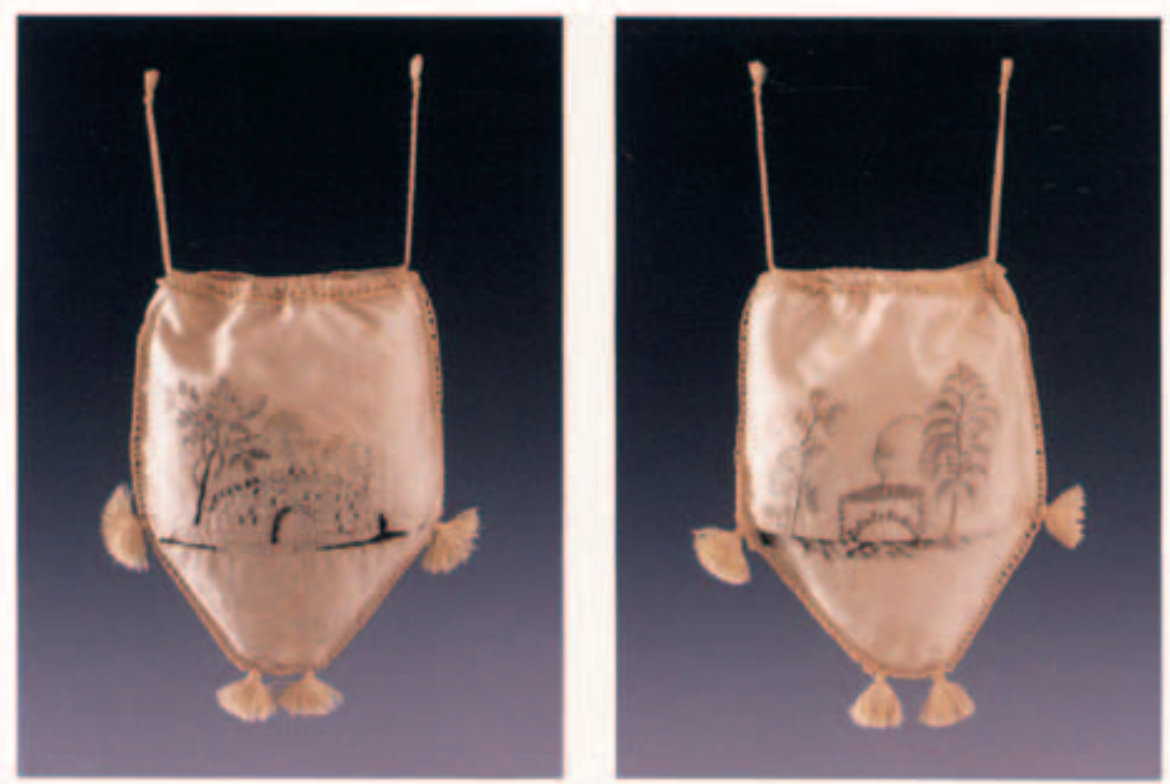

Il. 4. Torebka z tafty z katalogu Torebki, sakiewki i portfele ze zbiorów Muzeum Narodowego w Krakowie (s. 100) 
Jeszcze jednym przykładem stylistyki zdobień silnie powiązanej z duchem romantyzmu jest element romantycznego krajobrazu. Zawierają go dwa hafty. Jeden na torebce (nr inw. MNK XIX-5955, il. 4), drugi na portfelu z lat 20. XIX wieku (nr inw. MNK XIX-3530, il. 3). Pojawiają się wszystkie typowe elementy krajobrazu: mostek kamienny lub drewniany, wierzba płacząca lub inne (najlepiej pochylające się) drzewa, trawy bądź elementy ruin.

W wybranych przeze mnie przykładach zastosowano technikę haftu płaskiego, podobnie jak w haftach sztambuchowych. Nie należy jednak zapominać, że tego typu wzory były wykonywane również innymi technikami, w szczególności za pomocą bardzo popularnego haftu krzyżykowego lub petit point.

Przedstawione powyżej hafty sztambuchowe są ciekawym przykładem użycia tego popularnego elementu zdobniczego $\mathrm{w}$ formie sztambuchowego wpisu. Na podstawie powyższych przykładów, które dzieli 30 lat, widać zmiany zachodzące w stylach zdobniczych. Są one również świadectwem rozrywek dnia codziennego i kultury materialnej epoki.

\author{
KAROLINA NOWACZYK
}

\title{
Embroidery in the alba amicora held in the collections of Poznan University Library
}

\begin{abstract}
Aвstract. This article presents various examples of embroidery embellishments to be found in handcrafted books of friendship (album amicorum) from the eighteenth and the nineteenth centuries that are currently held at Poznan University Library. Techniques of handcraft embroidery as well as their craftsmanship and artistic value are discussed along with a wider discussion on the significance of the mentioned examples for the history of amateur embroidery developed in Polish lands. The article also attempts to draw attention of the reader to the art of embroidery of the time that was of purely amateurish character and points at many manifestations of a particular tendency to copy and repeat certain patterns which distinguished them as typical for the epoch.
\end{abstract}

KEY wORDs: books of friendship, embroidery, decorative art. 